Jurnal Ekonomi Syariah Teori dan Terapan p-ISSN: 2407-1935, e-ISSN: 2502-1508. Vol. 8 No. 5 September 2021: 530-536; DOI: 10.20473/vol8iss20215pp530-536

\title{
THE DETERMINANT FACTORS OF SOLVENCY ON SHARIA LIFE INSURANCE IN INDONESIA
}

\section{FAKTOR PENENTU SOLVABILITAS ASURANSI JIWA SYARIAH DI INDONESIA}

\author{
Yulita Widya Afiqah, Nisful Laila \\ Departemen Ekonomi Syariah - Fakultas Ekonomi dan Bisnis - Universitas Airlangga \\ yulita.widya.afiqah-2017@feb.unair.ac.id*,nisful.laila@feb.unair.ac.id
}

\begin{abstract}
ABSTRAK
Penelitian bertujuan untuk menilai ada tidaknya pengaruh ukuran perusahaan, pertumbuhan kontribusi, hasil investasi, dan likuiditas terhadap solvabilitas yang diproksikan dengan Risk Based Capital pada Asuransi Jiwa Syariah di Indonesia secara parsial ataupun simultan. Penentuan sampel dengan metode purposive sampling dan ditemukan 10 perusahaan sampel. Dengan bantuan aplikasi Eviews 9 melalui uji regresi data panel didapatkan persamaan $R B C=-563.8638+44.05145$ Ukuran +1.922926 Kontribusi 0.333289 Investasi +0.911149 Likuiditas $+e$. Hasil penelitian menunjukkan keempat variabel bersama-sama memengaruhi solvabilitas. Ukuran perusahaan memiliki pengaruh positif signifikan sementara itu pertumbuhan kontribusi, hasil investasi, dan likuiditas menunjukkan tidak adanya pengaruh terhadap solvabilitas Asuransi Jiwa Syariah di Indonesia periode 2015-2019.

Kata Kunci: Ukuran Perusahaan, Pertumbuhan Kontribusi, Hasil Investasi, Likuiditas, Solvabilitas, Asuransi Jiwa Syariah.
\end{abstract}

\section{ABSTRACT}

The purpose of this study isto determine whether there is an effect of company size, premium growth, investment returns, and liquidity on solvency as proxied by Risk Based Capital on sharia life insurance in Indonesia partially or simultaneously. Determination of the sample by purposive sampling method found 10 sample companies. With the help of Eviews9 application through the panel data regression test, it is obtained the equation $R B C=-563.8638+$ 44.05145 Size + 1.922926 Contribution - 0.333289 Investment +0.911149 Liquidity $+e$. The results showed that the four variables together affect solvency. Company size has a significant positive effect meanwhile the premium growth, investment returns, and liquidity shows no influence on the solvency of sharia life insurance in Indonesia period 2015-2019.

Keywords: Company Size, Premium Growth, Investment Return, Liquidity, Solvency, Sharia Life Insurance.

\section{INTRODUCTION}

Sharia Life Insurance is one way to protect and invest in a sharia-based community. The need that Moslem population to stay away from everything pertinent to usury allows it to survive and be tolerated by society. Sharia Life Insurance has a lot of promise and is expected to continue growing as more people realize its benefits. It is because more individuals realize the value of obtaining life insurance, especially because no one can foresee what may happen in the future. According to the Financial Services Authority Sharia IKNB Statistical Data for 2019, Sharia Life Insurance has the largest market share compared to General Insurance and Sharia Reinsurance till 2019.

Table 1.

In Indonesia, growth in Sharia Life Insurance capital, contributions, and investments from 2015 to 2019 (in Billion Rupiah)

\begin{tabular}{|l|c|c|c|c|c|}
\hline Indicator & $\mathbf{2 0 1 5}$ & $\mathbf{2 0 1 6}$ & $\mathbf{2 0 1 7}$ & $\mathbf{2 0 1 8}$ & $\mathbf{2 0 1 9}$ \\
\hline Asset & 21.614 & 27.079 & 33.484 & 34.474 & 37.487 \\
\hline Gross Contribution & 8.813 & 9.488 & 11.337 & 12.695 & 13.922 \\
\hline Investment & 19.576 & 24.565 & 30.417 & 31.882 & 34.327 \\
\hline
\end{tabular}

Statistics 2019 from the Financial Services Authority's Sharia IKNB. 
Since 2015, Sharia Life Insurance Companies have shown positive results. Table 1 shows that total assets reached Rp37,487 billion in 2019, with investment increase of Rp34,327 billion driving the expansion. It also has contribution income of Rp13,922 billion, indicating that Sharia Life Insurance is becoming increasingly appealing to the general population. As a result, life insurance firms must maintain their performance in order to satisfy the expectations of those who have entrusted their lives to them.

In comparison to other service industries, the financial component is the most significant supervisory aspect in the insurance service sector, whose performance assessment has its own criteria, notably by paying attention to solvency. Formerly, the minimum limit for sharia-compliant insurance and reinsurance companies was set by Minister of Finance Regulation 11/PMK.010/2011, which states that financial health has a solvency limit of 30\% for tabarru' funds and $70 \%$ for the health of the company's funds to account for the risk of losses. Companies are presently obliged to maintain the solvency of the Risk-Based Minimum Tabarru Fund (DTMBR) and the Risk-Based Minimum Capital (MMBR) of at least 120 percent each, according to the Financial Services Authority Regulation Number 72/POJK.05/2016.

The use of RBC as a health standard can provide legal protection for insurance clients so that they are not harmed by the company. RBC's high percentage implies that the company's capacity to pay the amount promised to consumers is improving. For Sharia Life Insurance businesses, the size of the $\mathrm{RBC}$ is a prerequisite in that the company is healthier and more secure. RBC is a risk-based financial control system that, in an ideal world, would be a healthy insurance business with a positive influence on its performance. Based on the foregoing, there is a need for relevant literature study on the factors that influence the solvency of Sharia Life Insurance businesses.

Various variable indicators are used in the study on measuring the solvency in Islamic Life Insurance firms. Based on past study in many countries that revealed various findings, the determination of factors is likely to have an impact on the solvency of Sharia Life Insurance. According to Srivastava \& Ray's (2013) research, company size had a strong influence on the solvency of insurance companies in India, as did research by Abduh \& Zein Isma (2017) and Abera \& Yirsaw (2020), but size companies were not significant to the solvency of insurance companies in Spain, contrary to Moreno et al., (2020). Contribution growth affected the solvency of Sharia businesses in Malaysia, (Abduh \& Zein Isma (2017), but Abera \& Yirsaw's (2020) research suggested that contribution growth had no influence on insurance companies in Ethiopia. The results of Abduh \& Zein Isma's (2017) research explained that investments had an influence on the solvency of Islamic firms in Malaysia, but Jawad \& Ayyash's (2019) research revealed that they had no effect on solvency. Liquidity had a favorable influence on insurance solvency in Ethiopia, (Abera \& Yirsaw (2020), while Jawad \& Ayyash (2019) stated thet liquidity had no effect on insurance firms in Palestine.

The introduction of laws relating to the minimum proportion of $\mathrm{RBC}$, which was first 30 percent and then increased to 120 percent, has presented Sharia Life Insurance businesses with a new difficulty. Furthermore, utilizing the variables of company size, contribution growth, investment returns, and liquidity to evaluate whether these factors affect solvency, this study is based on the discrepancies and inconsistencies in the results of previous research. The study's findings are designed to serve as a measuring tool for Islamic Life Insurance firms in Indonesia, offering a description of the company's performance that is helpful for internal purposes which are then taken into account when making financial solvency choices. The availability of this research for academics and the general public might become knowledge on the Sharia Life Insurance business's health as a reference resource, assisting in the decision of which Sharia Life Insurance company to follow. For academics working on the same issue, this study can serve as a point of reference and a foundation for future comparisons so that a subsequent study might be improved.

\section{THEORETICAL BASIS AND HYPOTHESIS DEVELOPMENT}

Sharia Life Insurance is a type of insurance that the Moslem community has selected as an alternative to evaluating the likelihood of future risks related to a person's life (Idris \& Darminto Hartono Paulus, 2020). According to Article 1 paragraph 9 of Law No. 40 of 2014, the same 
understanding is described, namely risk control efforts by bequeathing a number of costs both at the time of death and during the participant's lifetime, or also financing to participants who are entitled to receive in accordance with the consented agreement.

To maintain the Sharia Life Insurance company's condition so that it continues to expand and is balanced with rising public confidence, it is important to have oversight in managing the company's performance with the result that the company's performance is maintained. Maintaining the solvency value is one approach for insurance firm to sustain their financial performance. According to Srivastava and Ray (2013), solvency refers to a company's capacity to pay its claims. If the assets are insufficient (in comparison to the debt) or cannot be released in time to satisfy the claims that occur, the insurance will go bankrupt. When a company's assets can be utilized to pay off all of its liabilities, it is said to be solvable, and when the company's assets can't cover all of its commitments, it is said to be insolvent. Because the government has developed a rule on business solvency based on Risk Based Capital (RBC), RBC is used to indicate solvency in this study. The higher the RBC ratio, the better the insurance company's financial situation. By assessing a reporting entity's size and risk profile, the National Association of Insurance Commissioners (NAIC) defines RBC as a means of determining the minimum amount of capital necessary to sustain its entire business operations.

According to the most recent provisions regarding RBC in Indonesia, a Sharia Life Insurance company's target solvency level must be at least 120 percent of the value of the risk it faces, and the company must be equal to or greater than the limit of this provision to be considered in good financial health. RBC is a signal that Sharia Life Insurance firms must examine, especially if the RBC ratio is discovered as a result of a government decision. The establishment of this law serves as a tool for regulators to identify Sharia Life Insurance firms that are experiencing financial difficulties, allowing them to take preventative and remedial action (Fitriani, 2015).

A company's size indicates its capacity to complete the manufacturing process and deliver a variety of services to its consumers (Kigen, 2014). The Sharia Life Insurance company's solvency is influenced by its size since it demonstrates its ability to handle risks. Management may employ the company's assets more flexibly if the overall assets are high. The size of a corporation is determined by its total assets. Because the average loss of big firms is easier to forecast, large insurance companies have a low likelihood of default with the same amount of capital as small insurance companies (Moreno et al., 2020). Based on this explanation, the following hypothesis is proposed:

\section{H1: The size of a company has a major impact on its solvency.}

Contribution increase, according to Caporale et al., (2017), shows how successfully an insurance firm manages its core business. Insurance firms may expect their contribution growth to improve as public confidence in their services grows. Contribution growth indicates that the insurance business is in strong financial shape since it can forecast future revenue growth. The greater the contribution income is, assuming that the rise in contribution income is more favorably connected to RBC's growth. The following hypothesis is offered based on this explanation:

\section{H2: Increased contributions have a substantial impact on solvency.}

Investments are created by putting money into certain initiatives in order to benefit (Jawad \& Ayyash, 2019). Investment accuracy generates significant earnings for the firm and improves its solvency. A poor rate of return implies that the company's investment is not sound. Return on investment is needed to keep a company's finances in good shape, thus investments must provide significant returns. Higher investment income will assist the insurance business in meeting its commitments to policyholders, making it a key factor of solvency. Profitable investment revenue can help a firm avoid financial troubles and satisfy its responsibilities. As a result, insurance firms should steer clear of assets that are inadequately diversified and of low quality. The following hypothesis is offered based on this explanation:

\section{H3: Investment results significantly influence solvency}

Liquidity is defined by Jawad \& Ayyash (2019) as a company's capacity to pay its commitments within a set time frame. Because the liquidity ratio is one of the most straightforward indicators of financial health, its stability is a vital indicator of a company's solvency. Regulators may explore utilizing it as an early warning sign of potential financial distress. One of the most critical threats to an insurance company's solvency is liquidity. Liquidity, in basic words, refers to the 
resources and capability available to insurance firms to handle financial flows and guarantee that they can fulfill their obligations as they become due. The following hypothesis is offered based on this explanation:

H4: Liquidity has a major impact on solvency.

\section{RESEARCH METHOD}

Secondary data in the form of yearly financial reports is deployed using a quantitative approach. The sample was taken using purposive sampling method and the sample parameters were Sharia Life Insurance registered with the OJK for the 2015-2019 period, already had a business license in 2015, and published full yearly financial reports on the company's official website for the 2015-2019 period. The following ten Sharia Life Insurance firms were found using these criteria:

Table 2.

Company sample

\begin{tabular}{|c|l|}
\hline No. & Company name \\
\hline 1. & Family Takaful Insurance \\
\hline 2. & Sharia Life Insurance Amanahjiwa Giri Artha \\
\hline 3. & AIA Financial \\
\hline 4. & Allianz Life Insurance Indonesia \\
\hline 5. & Central Asia Raya Life Insurance \\
\hline 6. & Manulife Indonesia Life Insurance \\
\hline 7. & BNI Life Insurance \\
\hline 8. & Panin Daichi Life (formerly PT. Panin Life) \\
\hline 9. & Prudential Lift Assurance \\
\hline 10. & Tokio Marine Life Insurance Indonesia (formerly PT. MAA Life Assurance) \\
\hline
\end{tabular}

Source: Sample processing

The variables in this study are as follows:

1. Dependent Variable

Solvency is the company's ability to pay its claims (Srivastava \& Ray (2013). In this study solvency is represented through Risk Based Capital which is carried out with the formula:

$$
\text { Risk Based Capital }=\frac{\text { Solvency Level }}{\text { Minimum Solvency Level Limit }}
$$

2. Independent Variable

Table 3.

Independent Variable Formula

\begin{tabular}{|c|l|c|}
\hline No. & Variable & Formula \\
\hline 1. & Company Size & Ln Total Assets \\
\hline 2. & Contribution Growth & $\begin{array}{c}\text { (Increase (decrease) Contribution)/(Previous Year Net } \\
\text { Contribution) }\end{array}$ \\
\hline 3. & Investment Return & (Net Investment Income)/(Average investment 2 years) \\
\hline 4. & Liquidity & Current Asset \\
& & Current Liability \\
\hline
\end{tabular}

Source: Processed by the Author

The statistical tool Eviews9 is used to choose and execute panel data regression analysis. The first step in regression analysis is to choose the estimates that will be utilized in the analysis. The T test is used to test the association between variables, the $\mathrm{F}$ test is used to test the relationship between variables concurrently, and the Coefficient of Determination is used to assess the independent variable's contribution to explaining the dependent variable. 


\section{RESULTS AND DISCUSSION}

\section{Estimation Results of Panel Data Regression Model}

The Chow and Hausman tests were used to determine the regression model for the research panel data, and the results are shown in Tables 4 and 5 below:

Table 4.

Chow Test Result

\begin{tabular}{|c|c|}
\hline Effects Test & Prob. \\
\hline Cross-section F & 0.0000 \\
\hline
\end{tabular}

Source: Eviews9 result

The cross section probability value in Table 4 is 0.0000 less than $0.05(\alpha)$ and the Fixed Effect Model is chosen.

Table 5.

Hausman Test Result

\begin{tabular}{|c|c|}
\hline Test Summary & Probability \\
\hline Cross-section random & 0.0003 \\
\hline
\end{tabular}

Source: Eviews9 result

In Table 5 obtained probability is 0.0003 . This means that $<0.05$ that the model applied is the Fixed Effect Model.

\section{Coefficient of Determination Test $\left(\mathbf{R}^{2}\right)$}

With the provision of a value between 0 and 1, this test is used to assess the capability of the independent variable in describing the dependent variable. The following table shows the results of the R2 test:

Table 6.

Coefficient of Determination Test Result (R2)

\begin{tabular}{|c|c|}
\hline R-squared & 0.760839 \\
\hline Adjusted R-squared & 0.674475 \\
\hline
\end{tabular}

Source: Eviews9 Result

Table 6 shows that the R-squared value is 0.760839 , indicating that the independent variable's effect is 76.08 percent of the total, with the remaining 23.92 percent explained by the influence of other variables.

F-test

This test demonstrates that all independent variables have a joint influence on the dependent variable. Table 7 shows the test result:

Table 7.

F Test Result

\begin{tabular}{|c|c|}
\hline F-statistic & 8.809700 \\
\hline Prob(F-statistic) & 0.000000 \\
\hline
\end{tabular}

Source: Eviews9 result

Table 7 states the probability values. F 0.000000 where $<0.05$ which indicates the four variables together affect the solvency of the Sharia Life Insurance Company.

T-test the T Test:

This test is utilized to explain the partial relationship between variables. Here is the result of

Table 8.

T Test Result

\begin{tabular}{|l|c|c|c|c|}
\hline \multicolumn{1}{|c|}{ Variable } & Coefficient & Std. Error & t-Statistic & Prob. \\
\hline Size & 44.05145 & 7.269499 & 6.059765 & 0.0000 \\
\hline Contribution Growth & 1.922926 & 2.229469 & 0.862504 & 0.3941 \\
\hline Investment Return & -0.333289 & 0.940571 & -0.354348 & 0.7251 \\
\hline Liquidity & 0.911149 & 0.464667 & 1.960864 & 0.0577 \\
\hline
\end{tabular}

Source: Eviews9 result 
The probability value of company size is 0.0000 , less than 0.05 , as a consequence of statistical data processing, revealing the effect of variables on RBC. Meanwhile, with a variable coefficient of 44.05145 , a positive connection was found. The study's findings show that there is a significant positive relationship, thus $\mathrm{H} 1$ is accepted, implying that as a company's size grows, so does its solvency. The findings of the study are consistent with those of Srivastava \& Ray (2013), Abduh \& Zein Isma (2017), and Abera \& Yirsaw (2020), all of whom found it significantly positive. The capacity of Islamic insurance firms to guarantee risk is measured by their size. The value of the business's assets will increase as the number of people who join Sharia Life Insurance grows, reducing the risk of corporate instability. A Sharia Life Insurance company's capital is affected by an insurance business with a significant number of assets. The constant rotation of a business's capital has an influence on the flow of money; as capital turnover rises, the flow of cash back to the company becomes smoother.

The coefficient value of the contribution growth variable was 1.922926 with a prob value of 0.3941 after statistical data processing. When the probability of contribution growth exceeds $0.05, \mathrm{H} 2$ is rejected, indicating that there is no relationship between contribution growth and solvency. The findings of this contribution growth study had no discernible influence on Abera \& Yirsaw's findings (2020). According to Caporale et al., (2017), insurance companies frequently determine low-cost contributions as a result of the company's own errors in assessing the risk to be borne. As a result, the amount of contribution is insufficient for claim payments and the provision of promised benefits, causing the growth of contribution to have no effect on the solvency of the company. Furthermore, it is related to the link between the company's ability to cover costs and the likelihood of high expenses when contribution growth is strong. Despite the fact that the firm's contribution income has grown, the company's running expenditures have climbed significantly, forcing the revenue to be utilized to pay for corporate expenses.

The variable coefficient value of -0.333289 and the probability value of 0.7251 is the result of data processing. The chance of investment return increase is greater than 0.05 . In conclusion, H3 is rejected, indicating that investment return has no influence on solvency. The finding of this study agrees with Jawad and Ayyash (2019). Essentially, the profits and losses derived from investment results are determined by how the insurance business implements its investment policies, such that if the investment management is sound, the firm will achieve the desired investment results. Because the magnitude of investment returns has no bearing on a company's solvency, it's possible that Islamic Life Insurance firms in Indonesia are less accurate in their investment decisions, affecting earnings.

When statistical data processing yielded a significance value of 0.0577 or more with a variable coefficient of $0.911149, \mathrm{H} 4$ was discarded since no influence of liquidity on solvency was discovered, and it was found in the same direction as Jawad and Ayyash (2019). Neither an increase in liquidity nor a loss in liquidity has the ability to lead to bankruptcy. In this research, liquidity refers to the company's capacity to pay off debts within a year, whereas solvency refers to the company's ability to satisfy commitments for a year or longer. Because the firm is more likely to be able to pay its commitments on time with a bigger quantity of assets owned by the company, liquidity has no effect on the solvency of the company's finances. In other words, the insurance company has assumed responsibility for the firm's liabilities with a one-year maturity, thus there is no impact on solvency.

\section{CONCLUSION}

The results of the study show that business size has a positive relationship with Sharia Life Insurance in Indonesia's solvency, whereas contribution growth, investment returns, and liquidity have no influence. While company size, contribution growth, investment returns, and liquidity all simultaneously have an impact on Sharia Life Insurance companies' solvency in Indonesia. The research conclusion implies that firm should always maintain a constant company size in order to improve solvency and facilitate the flow of cash back to the company. 


\section{REFERENCES}

Abduh, M., \& Zein Isma, S. N. (2017). Economic and market predictors of solvency of family takaful in Malaysia. Journal of Islamic Accounting and Business Research, 8(3), 334-344. https://doi.org/10.1108/JIABR-06-2015-0030

Abera, H. B., \& Yirsaw, T. D. (2020). Firm specific determinants of general insurance business solvency margin: Evidence from Ethiopia, 11(3), 21-31. https://doi.org/10.9790/59331103052131

Caporale, G. M., Cerrato, M., \& Zhang, X. (2017). Analysing the determinants of insolvency risk for general insurance firms in the UK. Journal of Banking and Finance, 84, 107-122. https://doi.org/10.1016/j.jbankfin.2017.07.011

Fitriani, S. (2015). Pengaruh risk based capital terhadap profitabilitas asuransi syariah AXA Mandiri periode 2011-2013. Skripsi tidak diterbitkan. Bandung: Universitas Islam Bandung.

Idris, M., \& Paulus, D. H. (2020). Sharia life insurance: Legal basis and operational systems. Jurnal Hukum Prasada, 7(1), 45-52. https://doi.org/10.22225/jhp.7.1.1342.45-52

Jawad, Y. A. L. A., \& Ayyash, I. (2019). Determinants of the solvency of insurance companies in palestine. International Journal of Financial Research, 10(6), 188-195. https://doi.org/10.5430/ijfr.v10n6p188

Kigen, W. K. (2014). The effect of firm size on profitability of insurance companies in Kenya. Unpublished master thesis. Kenya: University of Nairobi Nove.

Moreno, I., Parrado-Martínez, P., \& Trujillo-Ponce, A. (2020). Economic crisis and determinants of solvency in the insurance sector: New evidence from Spain. Accounting and Finance, 60(3), 2965-2994. https://doi.org/10.1111/acfi.12422

Otoritas Jasa Keuangan. (2016). Peraturan Otoritas Jasa Keuangan Nomor 72/POJK.05/2016 tentang kesehatan keuangan perusahaan asuransi dan perusahaan reasuransi dengan prinsip syariah, 61 (2016). Retrieved from https://www.ojk.go.id/id/kanal/iknb/regulasi/asuransi/peraturanojk/Documents/Pages/POJK-tentang-Kesehatan-Keuangan-Perusahaan-Asuransi-danPerusahaan-Reasuransi-dengan-prinsip-syariah/SAL - POJK Kesehatan PAs PRs.pdf

Otoritas Jasa Keuangan. (2019). Statistik IKNB syariah periode Desember 2019. Retrieved from https://www.ojk.go.id/id/kanal/syariah/data-dan-statistik/iknb-syariah/default.aspx

Kementerian Keuangan. (2011). Peraturan Menteri Keuangan Nomor 11/PMK.010/2011 tentang kesehatan keuangan usaha asuransi dan usaha reasuransi dengan prinsip syariah. Retrieved from https://jdih.kemenkeu.go.id/fulltext/2011/11 pmk.010 2011per.htm

Srivastava, S. K., \& Ray, A. (2013). Benchmarking Indian general insurance firms. Benchmarking: An International Journal, 20(1), 4-24. https://doi.org/10.1108/14635771311299461 